\title{
Pre-sowing activation of seeds by ultraviolet (UV) radiation
}

\author{
Anvar Anarbaev ${ }^{1}$, Obid Tursunov ${ }^{1,2,3}$, Dilshod Kodirov ${ }^{1}$, Ibrokhim Khudaev, Khayrulla Isakhodjayev $^{1}$, and Sayid \\ Islikov $^{3}$ \\ ${ }^{1}$ Tashkent Institute of Irrigation and Agricultural Mechanization Engineers, 100000 Tashkent, Uzbekistan \\ ${ }^{2}$ Research Institute of Forestry, 111104 Tashkent, Uzbekistan \\ ${ }^{3}$ Gulistan State University, 120100 Gulistan, Uzbekistan
}

\begin{abstract}
The mechanism of influence the UV-radiation biological processes into seeds of agricultural plants is considered. The technical parameters of installation for pre-sowing treatment seeds with ultraviolet radiation lamps for increasing the permeability of biological membranes of cells in seed are defined. The results of experimental researches on have established that for processing of seeds cotton pre-sowing treated with ultraviolet rays, increasing of their germination and productivity of agricultural crops are shown.
\end{abstract}

\section{Introduction}

The current state of the agro-industrial complex requires the use of new environmentally friendly technologies for growing grain, vegetables and melons [1]. One of these technologies is pre-sowing activation of seeds by ultraviolet (UV) irradiation [2]. Presowing UV irradiation of seeds has a positive effect on increasing the yield of agricultural crops, increases their resistance to various diseases and unfavorable climatic factors (including drought, soil salinity). High processing efficiency depends on the use of special UV - emitters and automation of monitoring and control of the intensity of the radiation flux [3].

The mechanism of interaction of ultraviolet (UV) radiation on seeds has three components biostimulating, bactericidal and stress [4]. Under ultraviolet irradiation of seeds, the permeability of biological membranes of cells changes, which leads to stimulation of the initial growth processes [5]. The biostimulating effect of UV radiation on seeds is based on photoresonant rearrangement of their cellular structure and intracellular organelles [6]. As a result of UV irradiation in seeds, the level of lipid oxidation, $\mathrm{pH}$ and ATP activity change, which leads to an increase in bioenergetic and biosynthetic processes, which leads to an increase in the energy potential of seeds [7]?

In addition, irradiation of seeds with ultraviolet radiation leads to the destruction of phytopathogens, i.e. to disinfection of seeds (ecologically safe analogue of traditional dressing) [8]. However, it should be borne in mind that low doses of UV radiation do not have a significant effect on the microflora of seeds and cause a slight increase in germination, while high doses of UV radiation provide a more effective destruction of phytopathogens [9].

Along with this, high-intensity UV irradiation mobilizes genetically inherent growth reserves in seeds, which are due to the centuries-old adaptation of plants to solar radiation [10]. Under UV irradiation, seeds receive an unusually powerful informational effect, which introduces them into a state of stress [11]. As a result, the seeds mobilize their hidden resources, which are used to enhance the growth and development of plants [12]. Pre-sowing irradiation of seeds with ultraviolet radiation (UV) has a positive effect on increasing the yield of agricultural crops, increases their resistance to various diseases and unfavorable climatic factors, including drought and soil salinity [13-14].

\section{Research Methods}

The installation consists of a stand, a box for collecting the processed product, a gear motor, a drum (irradiation chamber) [15]. A loading hatch is located on the cylindrical side of the drum. A UV source is located inside the drum. The seeds are poured into the drum through the loading door (to ensure uniform irradiation of the entire product, the drum should be filled no more than $30 \%$ of its nominal volume). After finishing loading and closing the loading door, the drum is set in rotation. In this case, the UV radiation source located inside the drum is automatically switched on. The configuration of the UV lamps and the rotation speed of the drum are selected in such a way that uniform irradiation of all seeds loaded into the drum is achieved. The installation is controlled from the control case in automatic mode.

The design parameters of the installation have been determined, which is intended for pre-sowing activation of seeds of grain and vegetable crops with ultraviolet radiation. 
The installations consist of one or several irradiation modules fixed on the frame of the vibrating belt conveyor. Irradiation of seeds occurs during their passage through the irradiation zone. It is desirable to equip the conveyor with a vibrator for uniform irradiation of seeds. The design of the installation provides for the regulation of the suspension height of the irradiation modules, which allows for efficient seed treatment (Table 1).

Table 1. Design technical characteristics of the plant for UV irradiation of seeds

\begin{tabular}{|l|c|}
\hline Irradiation chamber volume, $\mathrm{m} 3$ & 0.25 \\
\hline One-time loading volume, $\mathrm{dm} 3$ & 75 \\
\hline Productivity (nominal), $\mathrm{kg} / \mathrm{h}$ & 250 \\
\hline The duration of the irradiation cycle, min & $2 \div 3$ \\
\hline Power consumption, $\mathrm{kW}$ & 0.4 \\
\hline Average resource of UV lamps, $\mathrm{h}$ & 9000 \\
\hline Irradiation module dimensions, $\mathrm{mm}$ & $1850 \times 650 \times 1420$ \\
\hline Control cabinet dimensions, $\mathrm{mm}$ & $400 \times 250 \times 600$ \\
\hline
\end{tabular}

\section{Results}

According to the materials of Table 2 , the lower the temperature is from $15 \div 16^{0} \mathrm{C}$, the more time is spent on germination of cotton seeds, and vice versa.

Table 2. Influence of temperature on the distribution of biomass and the number of cotton roots in the depth of the soil [16].

\begin{tabular}{|c|c|c|c|}
\hline \multirow{2}{*}{$\begin{array}{c}\text { Day/night } \\
\text { temperature, }{ }^{0} \mathrm{C}\end{array}$} & \multicolumn{3}{|c|}{ Soil depth, sm } \\
\hline & $<20$ & $20-40$ & $>40$ \\
\hline & \multicolumn{3}{|c|}{$\%$ to the total dry weight } \\
\hline $20 / 12$ & 96.2 & 3.3 & 0.5 \\
\hline $30 / 22$ & 93.3 & 4.4 & 2,3 \\
\hline $35 / 27$ & 94.8 & 2.8 & 2.4 \\
\hline \multirow[t]{2}{*}{$40 / 32$} & 88.7 & 7.4 & 4.0 \\
\hline & \multicolumn{3}{|c|}{$\%$ of the total number of root processes } \\
\hline $20 / 12$ & $71 \pm 3$ & $29 \pm 2$ & $0.1 \pm 0.0$ \\
\hline $30 / 22$ & $64 \pm 7$ & $36 \pm 4$ & $0.1 \pm 0.0$ \\
\hline $35 / 27$ & $58 \pm 3$ & $40 \pm 3$ & $2.0 \pm 0.3$ \\
\hline $40 / 32$ & $63 \pm 5$ & $35 \pm 2$ & $2.0 \pm 0.3$ \\
\hline
\end{tabular}

The same temperature limit is required from seedlings until the first true leaf appears. From the time of the appearance of the first leaf to the budding of cotton, an average daily temperature of at least $18^{\circ} \mathrm{C}$ is required; in the period from budding to flowering and from flowering to ripening for a medium-fiber variety, the average daily temperature should be approximately above $20^{\circ} \mathrm{C}[17]$. Studies carried out on a number of cotton varieties have established that agricultural crops for seeds treated with ultraviolet rays, their germination increased by an average of $20 \%$, and the yield increase was $35 \div 40 \%$.

Table 3. Results of UV treatment of crops (dry year)

\begin{tabular}{|l|c|c|c|c|c|c|c|}
\hline & \multicolumn{5}{|c|}{ Various varieties of cotton } & $\begin{array}{c}\text { Improvement of } \\
\text { indicators, \% }\end{array}$ \\
\cline { 2 - 7 } & unprocessed & $\begin{array}{c}\text { UV } \\
\text { treatment }\end{array}$ & unprocessed & $\begin{array}{c}\text { UV } \\
\text { treatment }\end{array}$ & unprocessed & $\begin{array}{c}\text { UV } \\
\text { treatment }\end{array}$ & \\
\hline Germination,\% & 72 & 93 & 71 & 90 & 72 & 92 & $21 \div 22$ \\
\hline $\begin{array}{l}\text { Germination } \\
\text { energy,\% }\end{array}$ & 70 & 72 & 69 & 73 & 92 & 79 & $3 \div 5$ \\
\hline $\begin{array}{l}\text { Productivity, } \\
\text { c/ ha }\end{array}$ & 22 & 37 & 23 & 35 & 39 & 39 & $35 \div 40$ \\
\hline
\end{tabular}

There is shown by the results of experiments on seed treatment carried out in the experimental field base "BMKBAgromash" (Table 3).

According to the researches [18-19], the lower the temperature is from $15-16^{\circ} \mathrm{C}$, the more time is spent on germination of cotton seeds, and vice versa. The same temperature limit is required from seedlings until the first true leaf appears. From the time of the appearance of the first leaf to the budding of cotton, an average daily temperature of at least $18^{\circ} \mathrm{C}$ is required; in the period from budding to flowering and from flowering to ripening for a medium-fiber variety, the average daily temperature should be approximately above $20^{\circ} \mathrm{C}$.

Presowing UV treatment of seeds also has a positive effect on increasing the yield of other cereals, melons and vegetables. Experimental studies have shown that UV treatment of wheat seeds increases its yield by an average of $30 \%$, corn by $40 \%$, barley by $10 \%$, pepper by $65 \%$, eggplant by $50 \%$, cucumber by $30 \%$, sugar beet - by $25 \%$, watermelons and melons - by $30 \%$ [20]. Along with this, the treatment of seeds with UV radiation has a positive effect 
on the increase in the content of sugar, vitamin $\mathrm{C}$, carotene, etc. In addition, there is an acceleration of the maturation of agricultural crops during $3 \div 15$ days [21-25].

\section{Conclusions}

Experimental studies have shown that the design technical characteristics of the plant for UV irradiation of plant seeds provide a good efficiency of the processes of their electrical treatment. Also a significant factor is the low price of UV equipment and the cost of pre-sowing seed treatment. Specific energy consumption for the technology of UV activation of seeds does not exceed $1 \mathrm{~kW} / 1$ ton of seeds

Thus, considering the profitability of this process, several components of the economic efficiency of pre-sowing treatment of seeds with ultraviolet radiation can be distinguished:

- the germination of plant seeds increases

- a significant increase in the yield of agricultural crops;

- increasing the export potential of grown products due to the lack of chemical stimulating reagents. In fact, the transfer of products to the category of organic farming is ensured.

\section{References}

1. V.N. Razzhevaikin, G.Yu. Shpitonkov, G.Yu. Maltsev, Modeling metabolic processes associated with environmental factors, VTs RAN, Moscow (1994)

2. I. Tahmasbian, A.A.S. Sinegani, Improving the efficiency of phytoremediation using electrically charged plant and chelating agents, Environ. Sci. Pollut. 23, 2479-2486 (2016)

3. G.W. Miller, V.D. Jolley, J.C. Brown, T.D. Davis, A.M. Barnes, Influences of ultra-violet (UV) -blue light radiation on the growth of cotton. II. Photosynthesis, leaf anatomy, and iron reduction, Journal of Plant Nutrition 10, $2283-2297$ (1987)

4. J.B. Dent, M.J. Blackie, System simulations in agriculture, Appl. sci. publ., London (1979)

5. F. Shaazizov, D. Shukurov, Physical modeling of the filtration process through the dam base, IOP Conference Series: Materials Science and Engineering 869, 7 (2020)

6. A.M. Mukhammadiev, The influence of electric impact on the growth, development and yield of cotton, Bulletin of Agrarian Science of Uzbekistan 1, 5-8 (2003)

7. A.M. Mukhammadiev, Electrotechnology of growing cotton, Agrarian Science 6, 12-14 (1996)

8. R.A. Zakhidov, A.I. Anarbaev, Combined system of solar heating and cooling using heatpump, Applied Solar Energy 50, (178-183) 2014

9. A. Anarbaev, A. Muxammadiev, S. Umarov, O. Tursunov, D. Kodirov, S. Khushiev, F. Muhtarov, Sh. Muzafarov, J. Izzatillaev, Mobile installations for electro treatment of soils and plants with the use of photovoltaic systems as power supply , IOP Conf. Series: Earth and Environmental Science 618, 012004 (2020)

10. A.I. Anarbaev, R.A. Zakhidov, Energy efficient and environmentally safed technologies using solar systems, hydrogen fuel cells and gas turbines, Applied Solar Energy 1, 68-72 (2011)

11. J. Jansen, Analysys of Counts Involving Random Effects Witj Application in Experimental Biology, Biometr. J. 35, 745-757 (1993)

12. A.M. Mukhammadiev, Electrotechnical means for the implementation of electrical technology for the production of raw cotton, Cotton growing and grain growing 3, 24-26 (2001)

13. F. Shaazizov, D. Shukurov, E. Shukurov, System for ensuring the detection and elimination of fires in the building of the hydroelectric power station, IOP Conference Series: Materials Science and Engineering 1030, 1 (2021)

14. J. Normuminov, A. Anarbaev, B. Xurramov, Utilizers of the condensing heat in the boiler's unit at heat power station of Uzbekistan, E3S Web of Conferences 216, 01123 (2020)

15. A. Anarbaev, O. Tursunov, R. Zakhidov, D. Kodirov, A. Rakhmatov, N. Toshpulatov, S. Namozov, E. Sabirov, Calculation the dynamic stability zone of the distribution grid with generating sources based on renewable energy, IOP Conf. Series: Earth and Environmental Science 614, 012004 (2020)

16. V.R. Reddy, K.R. Reddy, Z. Wang, Temperature and aldicarb effects on cotton roots growth and development, BIOTRONICS 26, 1-11 (1997)

17. B.C. Gazalov, N.Ye. Ponomareva, Influence of the modes of presowing treatment with ultraviolet radiation on the germination of winter wheat, Azovo-Chernomor. state agricultural engineer. 1, 46-49 (2004)

18. J.C. Bi, M. Schlaak, E. Siefert, R. Lord, H. Connolly, Alternating current electrical field effects on lettuce (Lactuca sativa) growing in hydroponic culture with and without cadmium contamination, J. Appl. Electrochem. 40, 1217-1223 (2010)

19. L. Xu, H. Dai, L. Skuza, Sh. Wei, Optimal voltage and treatment time of electric field with assistant Solanum nigrum L. cadmium hyperaccumulation in soil, Chemosphere 253, 126575 (2020)

20. R.R. He, G. Xi, K. Liu, Alleviating effect of extremely low frequency pulsed electric field on drought damage of maize seedling roots, J. Lumin. 188, 441-447 (2017)

21. O.A. Danilchenko, D.M. Grodzinsky, V.N. Vlasov, The value of ultraviolet radiation in the life of plants, Physiology and biochemistry of crops 34, 187-198 (2002) 
22. N. Toshpulatov, O. Tursunov, D. Kodirov, G. Kholmuratova, Environmentally friendly technology for the destruction of tobacco mosaic viruses (TMV) from selected species of plants, IOP Conf. Ser.: Earth Environ. Sci. 614, 012133 (2020)

23. J.W. Dobrowolski, O. Tursunov, O. Pirimov, O.J. Nazarova, Laser Biotechnology for Nutritional Health, Sustainable Environment and Development, IOP Conf. Ser.: Earth Environ. Sci. 614, 012108 (2020)

24. J.W. Dobrowolski, D. Bedla, T. Czech, F. Gambus, K. Gorecka, W. Kiszcak, T. Kuzniar, R. Mazur, A. Nowak, M. Sliwka, O. Tursunov, A. Wagner, J. Wieczorek, M. Swiatek, Integrated Innovative Biotechnology for Optimization of Environmental Bioprocesses and a Green Economy, Optimization and Applicability of Bioprocesses, eds H. Purohit, V. Kalia, A. Vaidya, A. Khardenavis, Springer, Singapore (2017)

25. J.W. Dobrowolski, J. Kobylarczyk, O. Tursunov, S.Q. Toh, Integration of Local Eco-Innovation with Global Problems of Protection of the Natural Environment and Bio-Based Green Economy, In Proceedings : AASRI International Conference on Circuits and Systems (CAS), Atlantis Press, 9 25-28 (2015) 